\title{
第一鉄還元容量法による硝酸または硝酸塩の迅速定量方法
}

\author{
村上徹 朗

\section{Rapid Volumetric Determination of Nitric Acid or Nitrate by Reduction with Ferrous Salt}

\author{
TETsuro Murakami \\ (Faculty of Industrial Chemistry, Kogakuin University)
}

\begin{abstract}
As a rapid determination of nitric acid or nitrate radical in sample acidified with concentrated hydrochloric acid, the solution was reduced with ferrous sulfate solution in the atmosphere of carbon dioxide, the $\mathrm{Fe}^{+3}$ thus formed was titrated, while hot, with a standard stannous chloride solution and the following results were obtained:

(i) An addition of $20 \mathrm{ml} 1 \mathrm{~N} \mathrm{FeSO}_{4}$ solution to $70 \mathrm{ml}$ concentrated $\mathrm{HCl}$ and boiling for 5 minutes resulted a complete reduction of nitrate radical.

(2) Application of this method to the determination of ammonium nitrate in concentrated ammonium sulfate solution gave a result in 10-12 minutes and the result agreed with that determined by nitrometer method.

(3) Application of this method to the determination of nitric acid in nitric acid-sulfuric acid mixture, and a correction was made by a separate determination of $\mathrm{N}_{2} \mathrm{O}_{4}$ in the mixed acid, gave a result agreed well with that of nitrometer method. (Received June 25, 1955)
\end{abstract}

\section{1. 緒 言}

従来硝酸根の定量にはナイトロメーターによる方法が 多く用いられているが，この方法は水銀を多量使用す ること, 発生した酸化效素ガスの容積測定によって硝酸 根を求めることなどによって種ぬの点で不便であり, ま た全操作に少くとも $30 \mathrm{~min}$ 以上の時間が必要で熟練し ないと結果に相当のバラッキがある.

Schultz-Ziemann 法"1は硝酸根を酸性で塩化第一鉄で 還元して NO ガスとして容積を測定しているが，これ に類似した反応を用いて硝酸根を容量分析する方法が文 献に見られる・たとえば濃硫酸酸性で硫酸第一鉄溶液で 滴定する方法2，塩酸酸性で第一鉄によって加熱還元す る方法などがあるが後者の場合, 硝酸カリウムを硫酸第 一鉄で還元し過剩の第一鉄を滴定して求める方法3)，硝 化綿 ${ }^{4}$ やニトログリセリン5) を酶酸に溶解し, 熄酸酸性 で塩化第一鉄または硫酸第一鉄で還元し，反応の結果生 じた第二鉄を塩化第一チタンで滴定して求める方法, そ の他 (⿻) 7) がある. 然しいずれも操作に相当長時間を要し ている.

著者は硝酸根を含む溶液を塩酸酸性とし，過剩の硫酸 第一鉄溶液を加えて加熱還元し, 反応の結果生じた第二 鉄を塩化第一スズ標準液で滴定する硝酸根の迅速定量方 法について研究し好成績を得たのて報告する. 本法は濃 厚な硫安溶液中の硝酸アンモニウムの定量, 硫硝混酸中 の硝酸の定量に好都合であって所要時間は 10 15 min であった.

\section{2. 試薬および器具}

(i) $0.1 N$ 塩化第二鉄標準液 市販 1 級品 $27 \mathrm{~g}$ を 6 $N$ 塩酸 $100 \mathrm{cc}$ にとかし塩素酸カリウム $2 \sim 3 \mathrm{~g}$ を加兄 加熱して還元性物質を酸化してから塩菜ガスを除き $1 l$

\footnotetext{
* 東京都新宿区角筈 2 -93
}

に稀釈した・本標準液の標定は過マンガソ酸カリウム樌 準液を用いて行った.

(ii) $0.1 \mathrm{~N}$ 塩化第一スズ標準液 市販 1 級品 $12 \mathrm{~g}$ を濃盐酸に溶解して $1 l$ に稀釈し，溶液の塩酸濃度は約 $3 N$ になるようにした .標定はつぎのように操作した。 $0.1 \mathrm{~N}-\mathrm{FeCl}_{3}$ 標準液の一定量を (vi) 飞記載の三角フタ スコにとり,これに約同容積の濃塩酸を加兄, 炎酸ガス 気流中で煮沸する程度に加熱してから本溶液で滴定した。 塩化第一スズ溶液は酸化されやすいので，貯蔵には下口 試薬ビンを用い、溶液の表面に $1 \mathrm{~cm}$ 位の厚さになるよ5 に流動パラフィンを浮かして直接空気と接触することを 防いだ.このようにして約 1 カ月の間測定した結果は 1 日に 1/500〜1/1000 の力価が変動する程度であった. 貯 蔵ビンは白色でも褐色でもほぼ同様の力価変動であった。 また本標潐液を通常使用する状態でビュレットに入れ放 置したが, $2 \mathrm{hr}$ までは本滴定法の精度に著しい影響をお よぼす程の力価変動は認められなかった。

(iii) $1 N$ 硫酸第一鉄溶液 結晶硫酸第一鉄を $1 N$ 硫 酸に溶解した、硫酸第一鉄中に訬量の $\mathrm{Fe}^{3+}$ が含まれ るが,これは空実験によって補正した．また本溶液に $\mathrm{Zn}$ アマルガムを入れて貯蔵したところ, $\mathrm{Fe}^{2+}$ の酸化防止 に有効であって空英墟值の变化を小範囲に止めることが 出来た.

(iv) $0.1 M$ 硝酸カリウム標準夜 特級硝酸カリウム を2回再結晶し， $130^{\circ} \mathrm{C}, 2 \mathrm{hr}$ 乾燥したすのを用いた.

（v）モリブデン酸アンモニウム溶液 市販 1 級品を 用いて $3 \%$ 水溶液を調製した.

(vi）還元および滴定用フラスコ $300 \mathrm{cc}$ 三角フラス コにコルク栓をし，これに炭酸ガス流出用のガラス曲管 をつけて用いた。

3. 定量操作 
還元用のコルク栓付三角フラスコに試料をとり $\left(\mathrm{HNO}_{3}\right.$ として $0.06 \mathrm{~g}$ 位) キップガス発生装置から $\mathrm{CO}_{2}$ ガスを 送りフラスュ中の空気を置換する.つぎに $\mathrm{CO}_{2}$ ガスを 通しながらピペットで硫酸第一鉄溶液 $20 \mathrm{cc}$ を加え，さ らにメスシリンダーを用いて濃塩酸 $70 \mathrm{cc}$ を加えて直 ちにアスベスト付金網上で加熱する．硝酸塩が存在すれ ばその量に応じて緑告色になり，1.5 min 位で混合溶液 は煮沸しはじめる．還元操作中の $\mathrm{CO}_{2}$ の流速は $300 \mathrm{cc} /$ $\min$ 位にする. 加熱 $4 \mathrm{~min}$ 位で還元は浪とんど完了す るが加熱 $5 \mathrm{~min}$ で焰を小さくし，引続き $\mathrm{CO}_{2}$ ガスを通 しながら直ちに塩化第一スズ標準液で滴定する. $\mathrm{Fe}^{3+}$ の 黄色が塩化第一スズ標準液の一滴で $\mathrm{Fe}^{2+}$ の淡緑青色に なる点をもって終点とする。

本法に使用寸る硫酸第一鉄溶液中には少量の $\mathrm{Fe}^{3+}$ が 含まれているので試料を用いず硫酸第一鉄溶液その他の 試薬の同量を用いて上記と同様に処理して空実験值を求 ぬ補正せね林ならない。

硝酸根の還元反応の化学方程式はつぎのよ5である.

$$
\mathrm{NO}_{3}{ }^{-}+3 \mathrm{Fe}^{2+}+4 \mathrm{H}^{+}=\mathrm{NO}+3 \mathrm{Fe}^{3+}+2 \mathrm{H}_{2} \mathrm{O}
$$

\section{4. 実験および実験結果}

(i ) 滴定終点判定実験 本定量法において還元によ って生成した $\mathrm{Fe}^{3+}$ を塩化第一スズ標準液で滴定する際 の終点判定に関して実験を行った．滴定時の試料溶液は 濃塩酸酸性であり，かつ温度が高いので硫青化カリウム を指示菜として用いることができなかった，溶液が濃塩 酸酸性で，かつ液温が $80^{\circ} \mathrm{C}$ 以上であれば溶液 $100 \mathrm{cc}$ に 対して $0.1 \mathrm{~N}-\mathrm{FeCl}_{3} 1$ 滴が存在しても明瞭な黄色を呈す るので，塩化第一スズの 1 滴によって $\mathrm{Fe}^{3+}$ の黄色が $\mathrm{Fe}^{2+}$ の淡緑青色になる点を終点にすることにした．被 滴定溶液中に硫酸第一鉄の含有量が多いと $\mathrm{Fe}^{2+}$ による 緑青色が濃くなって終点判定を困難にするおとれがある が，硝酸根還元用硫酸第一鉄溶液の添加は $25 \mathrm{cc}$ までな らば終点判定に何等の支障もおよぼさなかった.

(ii) 加熱還元の際の $\mathrm{FeCl}_{3}$ の損失 $\mathrm{FeCl}_{3}$ は比較的 に揮発しやすいので, 本法のよ5に濃塩酸酸性で炭酸ガ 不気流中で煮沸するとき $\mathrm{FeCl}_{3}$ の損失がどの程度であ るかを試験した。 $0.1 \mathrm{~N}-\mathrm{FeCl}_{3}$ 標準液 $25 \mathrm{cc}$ をとり特級 塩酸 $70 \mathrm{cc}$ を加光, 炭酸ガスを $300 \mathrm{cc} / \mathrm{min}$ 程度で通じ ながら $5 \mathrm{~min}$ 煮沸し直ちに炭酸ガス気流中で塩化第一 スズ標準液で滴定し，一方同様の操作をして煮沸しはじ めたならば直ちに滴定した值と比較した３回の実験と も両值が一致したので $\mathrm{FeCl}_{3}$ をこの程度の濃度で $5 \mathrm{~min}$ 煮沸しても $\mathrm{FeCl}_{3}$ の損失は本法の誤差範囲内であること がわかった.

（iii）空実験值の榆討 本定量法に使用する硫酸第一 鉄溶液は比較的安定な $1 \mathrm{~N}$ 硫酸酸性の溶液を使用して いるが，結晶硫酸第一鉄に含有されていた $\mathrm{Fe}^{3+}$ その他 不純物の影響, 溶液貯蔵中の酸化によって生じた $\mathrm{Fe}^{3+}$ の影響，還元のとき使用する塩酸の影響などを含めて空 実験を行い補正せねばならないのでこの点を検討した。 硫酸第一鉄アンモニウムは精製しやすく純度のよいもの が容易に得られるので，この固体 $10 \mathrm{~g}$ ( $1 N$ 硫酸第一鉄 溜液の約 $25 \mathrm{cc}$ に相当する) をとって空実験を行ったが,
空実験值を無視できる程小さくすることができなかった (塩化第一スズ僄準液消費量 $0.6 \mathrm{cc}$ 位). さらに使用す る塩酸に炭酸ガスを $3 \mathrm{~min}$ 通じて塩酸中の溶存酸素 (空 突験值に刘する塩酸の影響として塩酸中の溶存酸素の影 響がもっとも大きいと考えられる) を減少させて実験を 行ったが空実験值を $0.2 \mathrm{cc}$ (塩化第一スズ標準液消費量 として) 減少させるに止まったので, 迅速分析法として 試薬添加のよういなことを考えて，還元風としては硫酸 第一鉄溶液を使用することにした。

また本定量法では炭酸ガス気流中で $5 \mathrm{~min}$ 煮沸する ので炭酸ガス中に酸素の微量でもあれば空実験值の变動 の原因になると考えられたが，炭酸ガス気流中での煮沸 時間を $20 \mathrm{~min}$ に延長しても空実験值に影響をあたえな かった。

（iv）加熱還元時の塩酸濃度, 還元冏の濃度, 加熱時 間の影響試験 硝酸根を還元する反応式から, 者沸還元 するとさの塩酸濃度, 添加した還元剤の濃度, 加熱時間 が反汒の速さに大きく影響すると考えられたので実験を 行った. 試料として $0.1 M$ 硝酸カyウム標準液をとり, 触媒としてモリブデン酸アンモニウム溶液》” $0.2 \mathrm{cc}$ を加 え, 試料採取量, 硫酸第一鉄溶液添加量, 塩酸添加量, 加熱時間を变化させて迅速定量法としての条件を試験し た結果を第 1 表に示した. 第 1 表における回收率は硝酸 カリウムの純度を $100 \%$ とて算出した值である.この 実験結果加, 塩酸 $30 \mathrm{cc}$ 添 加 (約 $6 N-\mathrm{HCl}$ 酸性) て

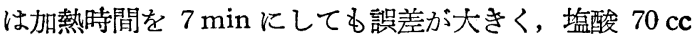
添加の場合に還元斉の添加量が $10 \mathrm{cc}$ では不十分であっ $\tau$, 塩酸 $70 \mathrm{cc}$ 添加 (約 $8.5 \mathrm{~N}-\mathrm{HCl}$ 酸性), 加熱時間 5 $\min$ で還元刜の $20 \mathrm{cc}$ を添加すれば定量可能であること がわかった。

第 1 表 $0.1 \mathrm{M}-\mathrm{KNO}_{3}$ 溶液中の $\mathrm{KNO}_{3}$ 定量結果 (還元凧の量, $\mathrm{HCl}$ の量, 加熱時間の影響試験)

\begin{tabular}{|c|c|c|c|c|c|c|}
\hline $\begin{array}{l}0.1 N- \\
K_{N O} \\
\text { 採取量 } \\
\text { (cc) }\end{array}$ & $\begin{array}{c}\mathrm{FeSO}_{4} \\
\text { 溶液添 } \\
\text { 加量 } \\
\text { (cc) }\end{array}$ & $\begin{array}{l}\mathrm{HCl} \\
\text { 添加 } \\
\text { 量 } \\
\text { (cc) }\end{array}$ & $\begin{array}{l}\text { 加熱 } \\
\text { 時間 } \\
\text { (分) }\end{array}$ & & \multicolumn{2}{|c|}{$\begin{array}{c}\mathrm{KNO}_{3} \text { 回収率 } \\
(\%)\end{array}$} \\
\hline 10.00 & 20.00 & 30 & 5 & 98.9 & 99.0 & \\
\hline 10.00 & "I & "I & 7 & 98.3 & 98.5 & 98.7 \\
\hline 10.00 & "I & 70 & 5 & $\begin{array}{r}99.8 \\
100.3\end{array}$ & $\begin{array}{r}1002 \\
99.9\end{array}$ & 100.2 \\
\hline 4.97 & 10.00 & "I & "I & $\begin{array}{l}98.0 \\
98.9\end{array}$ & 98.4 & 98.9 \\
\hline 4.97 & 20.00 & "I & "I & 100.4 & 100.4 & 100.2 \\
\hline 10.00 & 10.00 & "I & "I & 100.1 & 99.9 & \\
\hline 10.00 & 20.00 & "I & "I & 100.0 & 100.1 & \\
\hline 14. 97 & 'I & "I & "I & 100.2 & 100.2 & 99.8 \\
\hline
\end{tabular}

(v) 硝酸カリウム溶液中の硝酸カリウム定量

実験 (iv) の結果で塩酸 $70 \mathrm{cc}$ 添加, $1 N$ 硫酸第一鉄 溶液 $20 \mathrm{cc}$ 添加で $5 \mathrm{~min}$ 加熱すればよいことがわかっった が, $1 N$ 硫酸第一鉄溶液の添加量を $25 \mathrm{cc}$ として硝酸力 リウム標準液を定量し, 触媒としてのモリブデン酸アン モニウム溶液添加の有無の影響を試験した。モリブデン 酸アンモニウム溶液は $0.2 \mathrm{cc}$ 添加し実験結果は第 2 表 に示した. この突験の結果, 還元剤の添加量 $25 \mathrm{cc}$ の埸 
第 2 表 $0.1 M-\mathrm{KNO}_{3}$ 溶液中の $\mathrm{KNO}_{3}$ 定量結果

\begin{tabular}{|c|c|c|c|c|}
\hline $\begin{array}{l}0.1 M-\mathrm{KNO}_{3} \\
\text { 採取量 (cc) }\end{array}$ & \multicolumn{3}{|c|}{$\begin{array}{c}\mathrm{KNO}_{3} \text { 回収率 } \\
(\%)\end{array}$} & 備考 \\
\hline \multirow{3}{*}{10.00} & 100.2 & 100.3 & 99.9 & \\
\hline & 100.0 & 100.1 & 100.3 & (1) \\
\hline & 99.9 & 100.1 & & \\
\hline \multirow{3}{*}{10.00} & 100.3 & 100.2 & 100.1 & \\
\hline & 100.2 & 99.8 & 100.0 & (2) \\
\hline & 100.0 & & & \\
\hline 14.97 & 99.8 & 99.8 & & \\
\hline
\end{tabular}

(1); $\mathrm{FeSO}_{4}$ 溶液添加量 $25.00 \mathrm{cc}, \mathrm{HCl} 70 \mathrm{cc}$ 添加, 加 熱時間 5 分, 触媒添加.

(2); $\mathrm{FeSO}_{4}$ 溶液添加量 $25.00 \mathrm{cc}, \mathrm{HCl} 70 \mathrm{cc}$ 添加, 加 熱時閒 5 分, 触媒添加せず。

合は還元㶡の添加量 $20 \mathrm{cc}$ の場合と同様によい結果を示 し，触媒を添加しない場合も同様の結果を示した。この 試験の際, 外観上も触媒添加のため著しく反応速度が大 きくなる様に見えず，触媒添加量を 5 倍に増加しても同 様であった。すなわちこの実験の結果本定量法の条件で は触媒モリブデン酸アンモニウム溶液を用いなくても良 好な結果が得られることがわかった。

(vi）濃厚な硫安溶液中の硝酸アンモニウムの定量

濃厚な硫安溶液中に少量共存する硝酸アンモニウムの 定量に本法を応用して，ナイトロメーター法によってえ られた值と比較した. 試料として硫酸アンモニウム $35 \%$,

第 3 表 濃硫安溶液中の $\mathrm{NH}_{4} \mathrm{NO}_{3}$ 定量結果

\begin{tabular}{|c|c|c|c|c|c|c|c|}
\hline 試 & 料 & & 1 & & & 2 & \\
\hline $\begin{array}{l}\mathrm{NH}_{4} \mathrm{NO}_{3}(\%) \\
\text { (本 }\end{array}$ & 法） & (a) $\begin{array}{r}1.509 \\
1.501 \\
1.500 \\
1.511 \\
1.507\end{array}$ & $\begin{array}{l}1.510 \\
1.506 \\
1.506 \\
1.503\end{array}$ & $\begin{array}{l}1.500 \\
1.506 \\
1.512 \\
1.508\end{array}$ & (b) $\begin{array}{r}10.30 \\
10.29 \\
10.30 \\
\text { (c) } 10.28 \\
10.29 \\
10.27\end{array}$ & $\begin{array}{l}10.30 \\
10.25 \\
10.24 \\
10.28 \\
10.26 \\
10.29\end{array}$ & $\begin{array}{l}10.30 \\
10.28 \\
10.26 \\
10.27 \\
10.29\end{array}$ \\
\hline 平 & 值 & & 1.506 & & & 10.28 & \\
\hline \multicolumn{2}{|c|}{$\begin{array}{l}\mathrm{NH}_{4} \mathrm{NO}_{3}(\%) \\
\text { (ナイトロメーター法) }\end{array}$} & & 1.500 & $\begin{array}{l}4 \text { 回の } \\
\text { 平均值 }\end{array}$ & & 10.28 & $\begin{array}{l}3 \text { 回の } \\
\text { 平均値 }\end{array}$ \\
\hline
\end{tabular}

(a) $\mathrm{FeSO}_{4}$ 溶液 $25.00 \mathrm{cc}$ 添加, 触媒ナシ.

(b) $\mathrm{FeSO}_{4}$ 溶液 $25.00 \mathrm{cc}$ 添加, 触媒使用.

(c) $\mathrm{FeSO}_{4}$ 溶液 $25.00 \mathrm{cc}$ 添加, 触媒ナシ.

第 4 表 オキシム廃液中の $\mathrm{NH}_{4} \mathrm{NO}_{3}$ 定量結果

\begin{tabular}{|c|c|c|c|}
\hline 試 & 1 & 2 & 3 \\
\hline 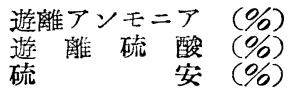 & $\frac{0.15}{35.9}$ & $\begin{array}{l}\overline{0.45} \\
36.8\end{array}$ & $\begin{array}{l}\overline{0.67} \\
34.7\end{array}$ \\
\hline $\begin{array}{l}\mathrm{NH}_{4} \mathrm{NO}_{3}(\%) \\
\text { (本法による值) }\end{array}$ & $\begin{array}{ll}2.457 & 2.488 \\
2.477 & 2.472 \\
2.458 & 2.466\end{array}$ & $\begin{array}{ll}7.23 & 7.24 \\
7.18 & 7.22 \\
7.18 & 7.18 \\
7.18 & 7.22\end{array}$ & $\begin{array}{ll}10.51 & 10.47 \\
10.54 & 10.43 \\
10.61 & 10.48\end{array}$ \\
\hline 平 均 值 & 2.471 & 7.20 & 10.51 \\
\hline $\begin{array}{l}\mathrm{NH}_{4} \mathrm{NO}_{3}(\%) \\
\text { (ナイトロメーター法) }\end{array}$ & $2.39_{3} \frac{2 \text { 平均値 }}{}$ & 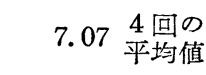 & $10.30 \begin{array}{c}4 \text { 回の } \\
\text { 平均值 }\end{array}$ \\
\hline $\begin{array}{l}\text { ナイトロメーター法に } \\
\text { 奶する相対誤差 (\%) }\end{array}$ & +3.3 & +1.8 & +2.0 \\
\hline
\end{tabular}

硝酸アンモニウム濃度が $1.5 \%$ よび $10 \%$ 種の試 料を調製し，このおのおのの試料中の硝酸アンモニウム を定量し第 3 表の結果を得た．硝酸アンモニウム $10 \%$ の場合はナイトロメーター法の值とよく一致した做が得 られ，そのバラッキも小さく，硝酸アンモニウム $1.5 \%$ の場合もナイトロメーター法の值に実用上差支ない一致 をみた。

つぎに本法を硫安溶液中の硝酸アンモニウム定量の実 際の試料に応用した。試料としてはシクロへキサノンオ キシム合成の際の廃液から硫安回收をする濃縮工程の液 を用いた・オキシム廃液は淡桃褐色から淡褐色虽色し ており少量の白色および黒色の沈澱物を含有し, 微アン モニア性かまたは微酸性であったが試料を科取する際に

第 5 表 $0.1 N-\mathrm{HNO}_{3}$ の定量結果 $\left(\mathrm{F}=0.874_{3}\right)$ （ナイトロメーター法による值 $\mathrm{F}=0.874$ 2回の平均值）

\begin{tabular}{|c|c|c|c|}
\hline $\begin{array}{l}\text { 試 料 } \\
\text { 採取量 } \\
\text { (cc) }\end{array}$ & $\begin{array}{l}\mathrm{SnCl}_{2} \\
\text { 標準液 } \\
\text { 消費量 } \\
\text { (cc) } \\
\text { (cc) }\end{array}$ & $\begin{array}{c}\text { 中和滴定值 } \\
\text { を標準飞し } \\
\text { た回収率 } \\
(\%)\end{array}$ & $\begin{array}{c}\text { ナイトロメー } \\
\text { ター法を標準 } \\
\text { にした回収率 } \\
(\%)\end{array}$ \\
\hline 10.00 & 26.18 & 99.8 & 99.8 \\
\hline "I & 26.18 & 99.8 & 99.8 \\
\hline "I & 26.24 & 100.1 & 100.1 \\
\hline "I & 26. 22 & 100.0 & 100.0 \\
\hline "I & 26. 24 & 100.1 & 100.1 \\
\hline
\end{tabular}

よくふりまぜて混濁つままで用いた，分析試料は 3 種で あって同一の濃縮工程のものを用いた. 実験結果は第 4 表に示したが，いずれも一様に相 対值としてナイトロメーター法に よる值より $1.8 \%$ ～ $3.3 \%$ 高值 をあたえることがわかった。しか し実験值のバラッキは小さかった。 高值をあたえる原因はまだ不朋で あるが，試料が着色し混濁してい ることから微量混在する酸化性物 質のためと考えられた。しかしこ の程度の偏りであれば旬速定量法 として実用可能であると考觉られ る. 本定量法の所要時間は 10〜 $12 \mathrm{~min}$ であったが, 作業中比重 測定が行われて打れば試料採取が 更に簡易化され5るので所要時間 8〜10 min に短縮できると考えて いる.

（vii）稀硝酸溶液中の硝酸定量 本法を $0.1 \mathrm{~N}$ の稀硝酸溶液中 の硝酸定量に応用した. 特級硝酸 を用いて稀硝酸溶液の試料を調製 し，この濃度を中和滴定法および ナイトロメーター法て求めて本法 による值と比較した。実験結果は 第 5 表に示したが本法によって定 量した值は中和啇定法およびナイ トロメーター法による值とよく一 致した。また試料と還元剤か添加 
第6表 硫酸混酸中の硝酸定量結果

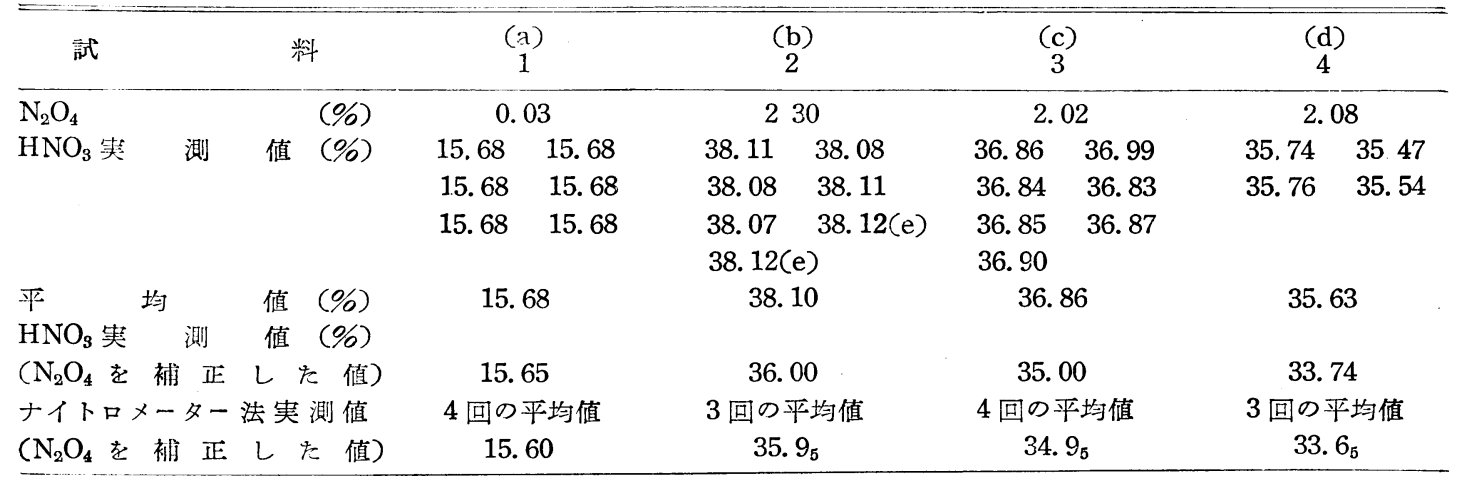

(a) 混酸試料 $\left(\mathrm{HNO}_{3}: \mathrm{H}_{2} \mathrm{SO}_{4}: \mathrm{H}_{2} \mathrm{O}=16: 65: 19\right)$, $18.396 \mathrm{~g}$ を $500 \mathrm{cc}$ に稀釈した.

(b) 混酸試料 $\left(\mathrm{HNO}_{3}: \mathrm{H}_{2} \mathrm{SO}_{4}: \mathrm{H}_{2} \mathrm{O}=38: 50: 12\right), 10.384 \mathrm{~g}$ を $500 \mathrm{cc}$ に稀釈した.

(J) 混酸試料 (2) の廃酸. $9.682 \mathrm{~g}$ を $500 \mathrm{cc}$ に稀釈した.

(d) 廃酸試料 (3) を硝化火使用した廃酸 $10.661 \mathrm{~g}$ を $500 \mathrm{cc}$ に稀釈した.

(e) 稀釈試料 $4.97 \mathrm{cc}$ をとり定量した.

順序を逆にして実験しても悪影響は見られなかったので, 還元棌添加前に炭酸ガス気流によって失われる硝酸の量 は無視出来ることがわかった。

(viii) 硫硝混酸中の硝酸定量

実験 (vii) の結果によって硝酸の迅速定量が可能であ ることがわかったので本法を硫硝混酸および硫硝混酸の 廃酸中の硝酸の定量に応用した. 硫硝混酸中には通常 $\mathrm{N}_{2} \mathrm{O}_{4}$ として $2 \%$ 前後の空素低級酸化物が含有されてい るが, ナイトロメーター法で硫硝混酸中の硝酸を求める ときはこの低級酸化物も硝酸として換算されるので, 別 に試料をとって過マンガン酸カリウム法その他でこの低 級酸化物を定量して補正せねばならない。

本定量法を硫硝混酸に応用寸る場合に, もし $\mathrm{N}_{2} \mathrm{O}_{4}$ が 存在すればつぎのような反応が起ると考えられる.

$$
\begin{aligned}
& \mathrm{NO}_{3}{ }^{-}+3 \mathrm{Fe}^{2+}+4 \mathrm{H}^{+}=\mathrm{NO}+3 \mathrm{Fe}^{3+}+2 \mathrm{H}_{2} \mathrm{O} \\
& \mathrm{N}_{2} \mathrm{O}_{4}+4 \mathrm{Fe}^{2+}+4 \mathrm{H}^{+}=2 \mathrm{NO}+4 \mathrm{Fe}^{3+}+2 \mathrm{H}_{2} \mathrm{O}
\end{aligned}
$$

このため $\mathrm{N}_{2} \mathrm{O}_{4}$ が存在すればその量を求めてその相当 量を補正せねば硝酸の量が求まらない筈である.この点 を実験するために各種の硫硝混酸を調製し本定量法を応 用した実験結果を第 6 表に示した.すなわら混酸試料の 一定量を科取し $500 \mathrm{cc}$ に稀瀵して, 稀橎試料 $10 \mathrm{cc}$ をピ ヘットでとり本法によって硝酸を定量し，一方ナイト口 メーター法によって硝酸を求めて両者を比較した. 混酸 試料中の空素低級酸化物 $\left(\mathrm{N}_{2} \mathrm{O}_{4}\right)$ は過マンガン酸カリウ 么酸化法で求めた. 混酸試料 (1) は試薬 1 級硝酸を用い て調薬した硝酸低濃度の混酸である. 混酸試料 (2) は発 煙硝酸（比重1.50）を用いて調製した混酸である.この 混酸試料 (2) を用いて, $1 / 70$ 重量のリンターを $18^{\circ} \mathrm{C}$, $30 \mathrm{~min}$ 硝化したときに生じた廃酸が混酸試料(3)である. 引つつきき混酸試料 (3) を用いて, 1/70 重量のリンター を $20^{\circ} \mathrm{C} 30 \mathrm{~min}$ 硝化してえた廃酸が湿酸試料 (4) である. 試料(3)拉よび(4)の廃酸はリンターの小片でかすかに濁っ ているものをそのまま使用した。

第 6 表の結果が示すように本法を硫硝混酸および硫硝 混酸廃酸中の硝酸の定量に応用するとき, 別に $\mathrm{N}_{2} \mathrm{O}_{4}$ 量 求めて補正すれば，ナイトロメーター法によく一致す
る実験值がえられた。また混酸に本法を応用した場合の 所要時間は 12〜15 min であった。

\section{5. 結 論}

硝酸根の迅速定量法として，硝酸根を孷酸ガス気流中 で濃塩酸酸性試料溶液に硫酸第一鉄溶液を加兄惹沸還元 乙, 反応の結果生成される $\mathrm{Fe}^{3+}$ を，加温のまま直ちに 酸化第一スズ標準液で滴定する方法を研究しつぎの結論 をえた。

(i) 塩酸添加量 $70 \mathrm{cc}$ (約 $8.5 \mathrm{~N}$ 塩酸酸性) て硫酸 第一鉄 $1 N$ 溶液 $20 \mathrm{cc}$ 以上添加し， $5 \mathrm{~min}$ 煮沸すれば硝 酸根は定量的に還元された。

(ii) 本法を濃厚硫安溶液中の硝酸アンモニウムの定 量に応用して 10〜12 min でナイトロメーター法によく 一致した值を得た.よってこの方法をシクロへキサノン オキシム廃液中の硝酸アンモニウムの定量に応用した.

(iii） 本法を稀硝酸溶液中の硝酸定量に応用したとこ ろ, 中和滴定法による值およびナイトロメーター法によ る值によく一致した。

(iv) 本法を硫硝混酸および硫硝混酸の廃酸に応用し た. 所要時間は 12〜15 minであった。

本研究を逐行するに当って種及御㯄切な御敎示を賜っ た工学院大学厚木勝基敉授, 東京大学荒木峻先生, 名古 屋大学平野四蔵敎授に深く感謝致します.

\section{文献}

1) Derée : Methods of Cellulose Chemistry, p. 231.

2) F. C. Bowman, W. W. Scott : Ind. Eng. Chem., 7, 766, (1915).

3) I. M. Kolthoff, E. B. Sandell, B. Maskovitz. : J . Am. Chem. Soc., 55, 1454 (1933).

4) W. E. Shaeffer, W. W. Becker : Anal. Chem., 25, 1226 (1953).

5) W. W. Becker : Ind. Eng. Chem., Anal. Ed., 5, 152 (1933).

6) W. J. Huff, R. D. Leitch : J. Am. Chem. Soc., 44, 2646 (1922).

7) P. Fainer : Can. J. Chem., 29, 46 (1951)., C. A., 45, 6156 (1951). 